\title{
Historicism in Legal Scholarship
}

\author{
Robert W. Gordont
}

In this Article I want to discuss some of the familiar ways in which legal scholarship deals with the fact that law exists in and must to some extent always be understood by reference to particular contexts of space and time. I shall be making and trying to support an argument that historicism, ${ }^{1}$ the recognition of the historical and cultural contingency of law, is a perpetual threat to the aims of our legal scholarship as conventionally practiced; that to defend against the threat (or to protect themselves from becoming aware of it) legal scholars have regularly and recurrently resorted to certain strategies of response and evasion; and finally, that these strategies have so influenced the practice of legal scholarship as severely to limit its intellectual options and imaginative range. In concluding, I will attempt to suggest some ways in which legal scholarship might break free of these limiting modes of response.

Some cautions and disclaimers before going on. In order to discuss within limited space how our legal scholars have dealt with the problem of historicism, and to cover a time period that is long enough to justify the claim that certain strategies regularly recur, I will have to summarize large bodies of thought rather rapidly and breathlessly, doubtless shearing them in the process of many of their strengths and subtleties. Moreover, as I hope will become clear, to say that work is vulnerable to criticism from the perspective of historicism is not at all to say that it is bad work. Even work whose every specific conclusion has been discredited can stand as a valuable contribution to the conversation of mankind. My project is not to criticize specific

$\dagger$ Professor of Law, University of Wisconsin. My thanks to David Hollinger for his comments on an early draft of this paper; to Barbara Black and Morton Horwitz for their comments at the symposium; to J.G.A. Pocock (whom I have never met), Charles Gray, and Elizabeth Mensch for teaching me most of what I know about the uses of history in legal thought; and to colleagues at the Buffalo and Wisconsin Law Schools for showing in their work how the "historicist" perspective can transform one's understanding of law.

1. As used here, the elastic term "historicism" refers simply to the perspective that the meanings of words and actions are to some degree dependent on the particular social and historical conditions in which they occur, and to interpretations and criticisms that are suggested by that perspective. It is not intended to describe the view that meanings may be derived exclusively by reference to the unique conditions of a specific time and place. 
pieces of work, but the process by which an intellectual dialogue has risked impoverishment by repeatedly failing to listen or respond to certain conversational moves.

I use "legal scholarship" to mean what might be called the mainstream elite scholarship of this country, the work of the acknowledged intellectual leaders of the profession. In the last century, before the rise of a separate profession of law teachers, this scholarship would have been that of the leading treatise-writers-Kent, Story, Greenleaf, Sedgwick, Parsons, and so forth; afterwards, the scholarship would be that of the writers of books and articles regularly cited or appearing in the leading law reviews. This restriction to "mainstream" scholarship is meant to exclude most of the work on law that emphasizes its historicity, like professional legal history, legal sociology, and legal anthropology; for the most part, this work is neither published nor cited in the leading reviews. But this restriction does not exclude a great deal of work done in other interdisciplinary modes; in particular, it includes the economic analysis of law and legal philosophy in the Anglo-American tradition of Hart, Dworkin, and Rawls. ${ }^{2}$

\section{The Threat of Historicism}

Mainstream legal scholarship thus defined seems to have three aims. ${ }^{8}$ The chief aim is that of rationalizing the real, of showing that the law-making and law-applying activities that go on in our society make sense and may be rationally related to some coherent conceptual ordering scheme. This task, which might be the theoretical attempt to develop or refine the ordering schemes themselves, or simply an effort to fit some specialized pattern of activity into already well-developed schemes, could be approached in almost any spirit, from true agnosticism about whether the real is rational to an assumption that it must be. For most scholars, I would guess, the approach is predetermined by the method: if one is doing legal scholarship at all, one is proceeding as if the real were rational. The second aim goes beyond rationalization to justification, because the basic ordering scheme is not interesting to most legal scholars-even to those who go to some pains to

2. See Tushnet, Legal Scholarship: Its Causes and Cure, 90 YALE L.J. 1205 (1981).

3. In the belief that the following account will not be controversial, $I$ have not tried to document it. The skeptical reader is invited to test it out for herself by looking through back numbers of any ten of what she would consider the leading law reviews. See Summary of Discussion of Historicism in Legal Scholarship, 90 YALE L.J. 1060, 1060 (1981) (confirmation of characterization by scholar at symposium) [hereinafter cited as Summary of Discussion]. 
characterize their method as positive and not normative4-unless the scheme may be derived from or at least shown to be consistent with some plausible conception of the good. Most writers doing "applied" rather than "basic" scholarship will seek only to refine the already developed justifications of existing ordering schemes, rather than starting from scratch every time. The third aim is a pragmatic one. Legal scholars usually want to persuade their readers that rationalization and justification are practical exercises that will help advocates or policymakers decide how to act or refrain from acting in social life and how to justify their actions publicly.

An intellectual exercise that satisfies all three of these criteria is necessarily somewhat apologetic, in either a conservative or reformist manner. The conservative reveals the hidden logical fit between what already happens in society and the underlying normative explanatory structure, then seeks to identify deviations or anomalies for the sake of casting them out. The reformer usually points to a whole body of ideas or practices that is out of line with the basic structure, but that can, with appropriate revisions, be made to fit. This exercise is apologetic because the assumption that existing practices are rational and good, or may readily be made so by procedures and options currently available to policymakers, tends to exclude consideration of other possibilities, such as that the practices are irrational or bad beyond the chance of correction save by fundamental change-in ways of thinking as well as in institutional design. In other words (to overstate somewhat): if the situation cannot be "fixed," it is not a "problem" for the field at all.

The legal activity that is the subject of this scholarship takes place in a society that exists in space and time. This society supplies materials to the rationalizing enterprise in several forms. The first might be called "legal texts." These are the basic data of the field, the workproduct of legal agencies and of lawyers doing or anticipating business before them, including cases, statutes, regulations, briefs, pleadings, indentures, deeds, settlement offers, negotiation arguments, advice to clients, and so forth. A second is the "social context," data from the social field in which the legal text is embedded. This could be the "facts" of a dispute, the "social problem" inspiring statutory action, the "difficulties of enforcement" of a tax levy or injunction, or the referent for the word "chicken" in a contract. The third set of materials will be called the "normative context," which is the apparatus

4. See Michelman, Norms and Normativity in the Economic Theory of Law, 62 MinN. L. Rev. 1015, 1038-39 (1978). 
of normative conceptions to which the legal scholar tries to relate the legal texts. Sometimes these conceptions can be derived from inspection of the texts alone. Sometimes they are imported from outside, from perceptions of customary morality, historical tradition, political economy, ordinary language, moral philosophy, and so forth. I trust that no one will suppose that normative and social contexts are meant to represent categories easily defined to be mutually exclusive.

Any use at all of these social materials, even pure doctrinal scholarship that restricts its scope to legal texts, will expose the user to historicist criticism. The critic will claim that the scholar has, in one way or another, seriously distorted reality by failing to take adequate account of the social and historical contingency of the materials. ${ }^{5}$ First, and least interestingly, the critic may try to swamp the rationalizing enterprise by emphasizing the bewildering and dense variety of the data it tries to manipulate. The scholar will come to see his legal texts as heaps of miscellaneous rubbish, and his attempts to sort them out as empty reductionist formalism. Some of the Legal Realists did have this experience, ${ }^{6}$ but it is not a common one among legal scholars.

A much more common experience is having to fend off the problems that arise because legal texts are "longitudinal" data, assembled by the scholar from earlier times. Principles synthesized from such texts are always open to the challenge that appeal to the old text is inappropriate because the social context has changed; the old text was drawn to respond to conditions that no longer exist. Of course, critical historicism at this level is itself part of the standard apparatus of legal scholarship. It poses no serious threat to the enterprise as a whole if kept on a tight leash, that is, if restricted to relatively trivial differentiation between past and present ("there were no cars traveling at 60 m.p.h. in 1850"), which implies that, saving such details, past and present are continuous. But historicism is dangerous whenever these restraints are loosened, as one can see from the recent powerful assaults by John Ely and Paul Brest on constitutional interpretation bound to textual language or the intentions of the drafters. Ely and Brest break with convention in positing drastic discontinuities, not only in social conditions and technologies, but in basic assumptions about reality ${ }^{7}$-about racial inferiority, the horror of death, or the necessary ineffectuality of judicial power.

5. Of course, legal scholarship is not unique in its vulnerability to this kind of criticism. See T. Kuhn, The Structure of Scientific Revolutions 1-3 (2d ed. 1970).

6. See G. Gilmore, The Ages of American LaW 80-81 (1977) (discussing Wesley Sturges's "intellectual nihilism").

7. See J. Elx, Democracy ANd Distrust 11-41, 45 (1980); Brest, The Misconceived Quest for the Original Understanding, 60 B.U.L. REv. 204, 220-21 (1980). 
The critic might go even further and make the case for discontinuity by reconstituting the political language in which an old text was first written. The old text will be rendered almost wholly archaic if it can be shown to embody a set of conceptions-about human nature, property, virtue, freedom, representation, necessity, causation, and so forth -that was a unique configuration for its time and in some ways strikingly unlike what we believe to be our own. ${ }^{8}$ One naturally thinks in this connection of the remarkable recent work that has made the thought of this country's founders enormously more intelligible by locating its terminology and major preoccupations in a Whig "republican" ideology with a foundation in Renaissance political thought." The lawyer who turns to the best available perspectives on the thinking behind the American Constitution may find herself in the position of the French humanist lawyers who hoped to uncover the universal basis for their own jurisprudence by freeing the Roman Corpus Juris from medieval corruptions, and then did such thorough scholarly work as to persuade many of them of Rome's irrelevance. ${ }^{10}$

Thus far, in this catalogue of perils, I have mentioned chaos and irrelevance. Perhaps more disturbing is the possibility that the critic, searching like the legal scholar for pattern and regularity in legal materials, will uncover a pattern, but not one that the scholar would wish to find. The critic might, for example, attempt to explain legal texts as determined, in an important sense, by some contextual variable such as the politics of a dominant class or temporarily dominant political coalition, the class affiliations of litigant parties or decisionmakers, the psychological makeup of officials, or the logic of some longterm historical trend, such as economic growth or the development of internal contradictions in capitalism. ${ }^{11}$ Such explanations will frequently be advanced because both ideologues of right and left and scholars

8. See generally J. Pocock, Languages and their Implications: The Transformation of the Study of Political Thought, in Polmtics, Language, and Time 3 (1971) (text must be understood in context of mindset embodied in language of the time it was written); Skinner, Meaning and Understanding in the History of Ideas, 8 HIsT. \& THEORY 3 (1969) (historian of ideas should uncover intended meaning of text by examining linguistic context).

9. See, e.g., J. Pococx, The Machinfeldan Moment 506-45 (1975); C. Rosbins, The Eighteenth-Century Commonimealthman 356-77, 385 (1959); G. Wood, The Creation of THE AMERican RepuBuic, 1776-1787, at 48-75 (1969); Dunn, The politics of Locke in England and America in the eighteenth century, in John Locke: Problems and Perspectives 45, 70.78 (J. Yolton ed. 1969).

10. See J. Frankein, Jean Bodin and the Stxteenth-Century Revolution in the MEthodology OF LAW AND History 36-58 (1963).

11. See, e.g., C. BeArd, An Economic Interpretation of the Constitution of the United States 152-88 (1913) (provisions of Constitution determined by distinct economic interest groups and classes); L. Friedman, A History of AmERICAN LAW 10 (1973) (American legal development not autonomous but molded by economy and society). 
in other disciplines have a profession.l stake in generating them. They are always a potential threat to the assumption that rationalizing legal texts will be a practical means of realizing the social good through law, because they seem to cast law, lawyers, and jurists in the humiliating status of mere epiphenomena, or at best, of people whose job it is to justify change brought about by forces over which they have little control. Curiously enough, however, legal scholarship has enthusiastically embraced certain kinds of social determinism. ${ }^{12}$

More subtle threats than these determinisms arise out of explorations of context that challenge the models of instrumental rationality underlying both the liberal theory of law and the enterprise of legal scholarship. These models assume that legal rules, if they are living up to their potential, are both universalistic and efficacious. ${ }^{13}$ Nobody is bothered if the historicist questions this picture by pointing to specific laws that are selectively or ineffectively enforced: these examples simply illustrate the "gap" between law on the books and in action, the deviant practices that it is the function of legal scholars to extirpate. ${ }^{14}$ What is troubling to legal scholars is the sociology that demonstrates systematic discontinuities between legal texts and their contexts. There are many different ways of creating this sense of discontinuity. One is an anthropological approach, "legal pluralism," which demotes the legal order to the status of one subculture among many, competing (and often losing) against many other sources of normative order and coercive sanctions, especially the customary orders of private associations. ${ }^{15}$ Viewed this way, legal forms may not appear primary and universal, but seem only to express the ideology of a particular official or professional group-lawyers, judges, members of Congress, police officers, school administrators-the content of which is determined by the group's strategy of self-aggrandizement, which may include mystification, the pose of guarding traditional norms, the

12. See pp. 1028-33 infra (discussing adaptation theory).

13. See Trubek \& Galanter, Scholars in Self-Estrangement: Some Reflections on the Crisis in Law and Development Studies in the United States, 1974 Wis. L. REv. 1062, 1070-74 (discussing paradigm of "liberal legalism").

14. On the "gap" and its functions in legal scholarship, see Abel, Law Books and Books About Law, 26 STAN. L. REv. 175, $184-89$ (1973), and Feeley, The Concept of Laws in Social Science: $A$ Critique and Notes on an Expanded View, 10 LAw \& Soc'Y REV. 497, $498-500$ (1976).

15. See, e.g., M. Galanter, Justice in Many Rooms 3-4 (1979) (unpublished Disputes Processing Research Program Working Paper, \#1979-4, University of Wisconsin Law School); Macaulay, Non-Contractual Relations in Business: A Preliminary Study, 28 AM. Soc. REv. 55, 62 (1963) (in many business transactions, law of contract and legal sanctions play only a small role); Mayhew, Stability and Change in Legal Systems, in Stabiury and Soctal Change 187, 188, 210 (B. Barber \& A. Inkeles eds. 1971) (legal system cannot exercise control over many autonomous social institutions and organizations). 
seizure of initiative from some other agency, or election to political office. Alternatively, the embodiment of a norm in law may be a tribute to its very ineffectiveness, the legal system being assigned the role of expressing as pious hopes norms that no one expects ever to be actualized. ${ }^{16}$ Conversely, norms that derive from sources other than the state may be quite effectively enforced: in a society like ours, with strong traditions of extralegal ${ }^{17}$ and antilegal ${ }^{18}$ ideologies, one cannot even assert with confidence that the state has held a monopoly on legitimate violence. What legal scholarship considers the normal casethe law effective according to its announced terms and evident purposes-is relegated to a subclass of events satisfying peculiar and rather unusual social conditions. ${ }^{19}$

Other critics use evidence internal to the legal system to support the thesis of discontinuity, showing, for example, that requirements of procedure clutter every expression of substantive law with elaborate conditions on the means of its application. Rules apparently intended to create liabilities of $B$ to $A$ may submit $A$ to painful assaults on privacy and dignity, may put $A$ to difficult and expensive proof, may be conducted in a language difficult to understand and alien to A's concerns, and may be enforced by an agency congenitally sympathetic to B; such a rule will frequently end up making B stronger than ever. Again, mainstream scholarship expects this result to happen sometimes, and even concedes that it happens in whole areas of law, ${ }^{20}$ but does not admit that it will happen in the typical case.

Many more examples might be given. The point is that these types of social investigation and historicist criticism are profoundly unsettling to the standard rationalizing modes because they suggest that the contributions of texts to contexts are as likely to be harmful or futile as beneficent or practical, for reasons that ordinary legal analysis seems

16. See, e.g., M. Edelman, The Symbolic Uses of Poltics 37.38, 47.49 (1964); J. GusField, SYMBolic CrusAde 166-71 (1963).

17. See, e.g., J. ReId, IN A RebeluIous SPIRIT 86.87 (1979); Maier, Popular Uprising and Civil Authority in Eighteenth-Century America, 27 William \& MARY Q. 3, 21-33 (1970). Although both Maier and Reid argue that mob action during the American Revolutionary period could be, and was, rationalized as lawful, that action was nonetheless at odds with officially constituted authority.

18. See A. Himimert, ReLigion ANd the American Mind 179.82 passim (1966) (discussing colonial sources of evangelical antilegalism).

19. See Felstiner, Influences of Social Organization on Dispute Processing, 9 LAw \& Soc'y REv. 63, 80-83 (1974); Galanter, Why the "Haves" Come Out Ahead: Speculations on the Limits of Legal Change, 9 LAW' \& Soc'Y REv. 95, 149.50 (1974); Griffiths, Is Law Important? 54 N.Y.U. L. REv. 339, 369-74 (1979); Simon, The Ideology of Advocacy: Procedural Justice and Professional Ethics, 1978 Wis. L. Rev. 29, 119-30.

20. To some extent administrative regulation and lower level criminal justice administration have been assigned a special status even in mainstream scholarship as examples of persistent discontinuity between overt textual intentions and actual social operation. 
to keep beyond its field of vision. Derhaps more disturbingly, they suggest that the legal text often may not be understood at all in terms of its instrumental relation to a social context, but only as a symbolic statement: a legitimating ideology, a utopian aspiration, or a cultural ritual designed to define boundaries between social cleanliness and defilement. In response, legal scholarship has developed theories of how law relates to society and to history that minimize these threats to its enterprise.

This is not to say that most or even many legal scholars actually feel threatened by criticism from the historicist perspective; far from it. ${ }^{21}$ For one thing, the "applied" work of many middle-level scholars is far enough away from organizing theoretical assumptions that they would not be likely to see assaults on those assumptions as even relevant, much less damaging. To generate the psychological experience of a threat, the critic would first have to encourage such scholars to articulate the theoretical structures they take for granted. For another, the virtue of the "responsive modes" I am about to discuss is precisely that they provide a means to keep any sense of being threatened at bay. This quality is well illustrated by the fact that, although my argument as it has developed has tended to cast legal rationalism in a conservative role, and empiricism and historicism in a subversive and critical one, our experience has been largely the opposite. In the past, legal history has on the whole served to bolster and reassure existing enterprises of legal scholarship $\mathrm{p}^{22}$ and has required powerful assistance from criticism of very different forms-for example, Bentham's analytic demonstration of Blarkstone's internal incoherence ${ }^{23}$ or Tom Paine's radical fundamentalist attacks based on natural rights ${ }^{24}$ -to break up these cozy, historically based systems. Nonetheless, historicist criticism, as I will argue, has also played a part in forcing major shifts in legal scholarship. Indeed, historicist criticism is always ultimately destabilizing to the enterprise. Hence the need for strong defenses.

\section{The Failure of the Responsive Modes}

I will classify the responsive modes in four categories. The first mode is denial that particular contexts of time and place are relevant

21. Barbara Black and others raised this point at the symposium. See Summary of Discussion, supra note 3, at 1060.

22. See Horwitz, The Conservative Tradition in the Writing of American Legal History, 17 AM. J. Legal Hist. 275, 276, 281 (1973).

23. See J. Bentham, A Comment on the Commentaries, in A Comment on the Commentaries and A Fragment on Government 1 (J. Burns \& H. Hart eds. 1977).

24. See T. Paine, Rights of MaN (2d ed. London 1791) (1st ed. London 1791). 
to the enterprise of legal rationalization. The second is Cartesianism, the construction of drastically simplified models of social reality for use in legal analysis. The third is embrace of context, or assimilation, in such a way that social and historical contextualization seem to serve rather than to subvert legal rationality. The fourth is resignation in the face of social contingency and historical change.

Denial. The purest form of denial is to assert that legal reasoning's exclusive concern should be to work out the relationship of legal texts to a system of suprahistorical norms transcending time and space. In this view, reason is, by definition, deduction from universals, not induction from the temporary and contingent. This style of naturallaw thinking need not detain us. In the sixteenth and seventeenth centuries, empirically and historically minded lawyers, among others, helped to ensure its relegation to the margins of elite legal thought by shifting the center of study to positive law-the specific legal practices of actual societies-and by developing a self-consciously inductive method for deriving legal principles from experience. ${ }^{25}$ Of course, naturallaw thinking has since remained vital, but I doubt that anyone would claim that its pure form is any longer in the mainstream. To the extent it persists, it is almost always mixed with other modes.

The modern forms of denial are likely to stake out only limited claims for the territory of suprahistorical norms. One example might be the "originalist" view of the interpretation of the Federal Constitution, which claims that at least some texts must be treated as if they had a frozen, noncontingent meaning. For reasons already suggested, this is an exceedingly difficult position to put into practical operation. ${ }^{20}$ Another example might be the view that many, though not all, legal rules are technical, facilitative rules used to solve problems of a kind that might arise in any society (such as rules governing the formalities of contract formation) and can therefore be expressed in an abstract form to which any society at any point in its mutation could plug in. Yet denial even in this form cannot successfully defend the rationalizing enterprise. One of the standard, and most effective, historicist attacks made by the Realists on their "formalist" predecessors involved the formalists' claims to have come up with such rules. The supposedly purely technical schemes of offer-and-acceptance rules, for instance, were shown to be indefinitely manipulable in theory to reach the results of "contract formed" or "no contract formed" in any particular case, and to have been regularly

25. See W. Gruenteat, Ordek, Empiricism, and Polmtics 142-205, $262-82$ (1964); J. Pococx, supra note 9 , at $\mathbf{3 - 3 0}$.

26. See p. 1020 supra. 
manipulated in practice to reach one result or the other in situations that could be distinguished only by close attention to social or economic context. 27

Cartesianism. The much more common modern strategy for keeping distressing historicity at bay is what I call "Cartesianism": formal modelling, the intellectual strategy of constructing highly simplified models of social reality for the sake of analytic rigor and elegance, in the manner of economic theory. The models are relatively closed games. You cannot play unless you agree in advance to a fairly explicitly specified set of rules about permissible moves. If you change the rules-for example, by admitting a new empirical assumption: the island people produce three goods, not just two, and one person is given a gun-you should change only a few at a time and only with advance notice. Cartesianism is a strategy midway between the denial and the embrace of social contingency: it admits social variables, but only as members of a highly exclusive club, and thus makes itself vulnerable to historicist attack only to the extent it desires.

The legal formalism of the late nineteenth century was a Cartesian mode in this sense, because many of its practitioners viewed the few core principles on which it was based as socially derivedindeed, as given by history. But history was a subcontractor whose job was finished once it had laid the foundation of principles. The rest of the structure was to be built strictly with such legal texts as could be rationalized according to deductions from those principles, ${ }^{28}$ with allowances here and there for quirks of public policy. The Realists had a lot of fun with these structures, pointing out the social contingency of decisions and the policy choices made with the placing of every brick and board. ${ }^{29}$ Nonetheless, they too practiced, and bequeathed to us, a quasi-Cartesian method of "policy analysis" that employs a simple model. That model assumes that the rules of appellate doctrine are instantly incorporated in the incentive structures of individuals situated like the litigants, and takes the "facts" as stated in the opinion, for the purpose of analyzing the effect of rules, to represent the litigants' situation. For example: "Adoption of the rule plaintiff wants would ... deter sellers from fraud, cause

27. See, e.g., Cohen, Transcendental Nonsense and the Functional Approach, 35 Colum. L. Rev. 809, 839-42 (1935); Llewellyn, On Our Case-Law of Contract: Offer and Acceptance (pts. 1 \& 2), 48 YALE L.J. 1, 779 (1938-1939).

28. See C. Langdelt, A Summary of the Law of Contract iv (2d ed. 1880) ("a concise statement and exposition of the doctrines" developed in his pioneering cascbook).

29. See pp. 1025-26 supra. 
them to charge higher prices, leave the market in disgust," and so forth.

Historicist critics have treated policy analysis harshly, though with no apparent effect upon its incidence. The critics assert that because of high litigation costs, cross-cutting regimes of social custom or domination, total lack of correspondence between the way the judge told the story and the way the litigants experienced it, or the impracticability of general enforcement, announcement of the rule is likely to have no effect at all, or to have a completely unexpected one. ${ }^{30}$ Yet the vulnerability of Cartesian modes to the battery of historicist criticisms naturally depends on the claims made for the theory. Sir Henry Maine's famous objection to Austin's notion that law is the command of a sovereign-that in many of the world's societies, past and present, one could not find anyone looking like a sovereign issuing anything looking like a command, because their members' habits of obedience are overwhelmingly to orders of custom ${ }^{31}$-was beside the point. Austin was not trying to describe any actual legal system, just proposing a model to sharpen thinking about the idea of law generally. But the moment that positivist theorists like Austin claim the ability to resolve actual social controversies through a reasoning process that is strictly internal to an autonomous legal order, relying exclusively, for example, on the "core meanings" of authoritative legal texts (rules), the historicist is entitled to point out that all language is social, and all meaning contextual. ${ }^{32}$ Similarly, modern policy analysts might argue to their critics that the normative enterprise of rationalizing doctrine is one that traditionally proceeds as if the model were empirically valid, so that demonstrations that it is not are irrelevant ${ }^{33}$ Further, if one wishes to converse with judges in their rhetorical reasoning modes, one will adopt their simplifying assumptions, however fanciful they may seem. Yet few legal scholars are willing to see their enterprise as simply one of working within traditional rhetorics. To the extent that, as problem-solvers, they must claim that their models represent social reality well enough to be used

30. See, e.g., Macaulay, Elegant Models, Empirical Pictures, and the Complexities of Contract, 11 LAw \& SOC'Y REV. 507, 508-10 (1977).

31. See H. MAINe, Lectures on the EArty History of Institutions $357-65$ (1888).

32. See p. 1021 supra; Fuller, Positivism and Fidelity to Law-A Reply to Professor Hart, 71 Harv. L. Rev. 630, 661-69 (1958).

33. Perhaps this answer is rarely given because it is so easily followed by the question: "But if you are not seriously interested in instrumental effects, why do you use a rhetoric of instrumental rationality?" This challenge requires a more complicated (and equally rare) answer, perhaps: "At present instrumental rhetoric is the most legitimate and persuasive." 
as a basis for decisionmaking, they sre fair game for their critics. ${ }^{34}$ Adaptation Theory. Even at the flood tide of formalism in American legal scholarship, at the Harvard Law School of the 1870s and 1880s, the scholars were committed as much to the project of synthesizing legal principles from historical materials as to analytic schematization of those principles. Like Austin himself, who had studied in Germany and was convinced he was pursuing a genuine historical method, ${ }^{35}$ they were certain that the historical and analytic methods complemented rather than conflicted with one another. In short, they had found a way of accepting a relationship between legal texts and society, but one seemingly free of historicist perils. This brings us to the third and most important of the responsive modes, the notion that there is an immanent rationality in social life, which it is the business of legal rationalization to incorporate.

One way of embracing history, now rarely used explicitly, is as a curator of timeless traditional wisdom or immemorial custom-the norms of the ancient Gothic Constitution or those of 1787-which is frequently violated in times of tyranny, but always there to be reaffirmed once people come to their senses. ${ }^{36}$ Some versions of this static view of the function of tradition have always been important in our legal thought, ${ }^{37}$ but only in combination with much more important dynamic views of history. Their exponents have kept up a steady barrage of criticism against the static views without ever managing to expel them entirely. The critical technique is simply to show that the custom or ideal claimed to be immemorial has a specific origin in the circumstances and thinking of a particular period, and survived after it only as a result of inertia. ${ }^{38}$ The point of departure for this kind of criticism is the adaptation theory of legal change, which,

34. Cf. Rizzo, The Mirage of Efficiency, 8 HofsrRA L. REv. 641, 641-43 (1980) (models of legal economics exclude too many variables to be useful).

35. See $2 \mathrm{~J}$. Austin, Lectures on Jurisprudence 701.02 (4th rev. R. Campbell ed. London 1873) (Ist ed. London 1861) (new material in Campbell edition taken from John Stuart Mill's notes); Schwar, John Austin and the German Jurisprudence of His Time, 1 Poutica 178 (1984).

36. See J. Pocock, The Ancient Constitution and the Feudal Law 30.55 (1967) (characterizing early 17th-century conception of common law as immemorial custom); R. Welter, The Mind of Americs, 1820-1860, at 26-44 (1975) (post-Revolutionary Americans believed that they had transcended the "macrohistory" of the European old world, and were to live in a "microhistory" in which the problem would be striving to live up to norms already given by the national mission); cf. S. BERCovitch, The AMErican JereMIAD 93-131 (1978) (discussing "America's Mission").

37. See T. Jefrerson, Whether Christianity is Part of the Common Law? in 1 THE WrITINGs of Thomas JeFferson, 1760-1775, at 360 (P. Ford ed. 1892).

38. See, e.g., J. BenthaM, supra note 23, at 234-37; J. Pocock, supra note 36, at 91123 (discussing work of Sir Henry Spelman). 
from its first full articulation (perhaps never since surpassed) by Matthew Hale, ${ }^{30}$ has become central to our conventional ways of thought.

Adaptation theorists sometimes say that the function of law is to learn to recognize, or imitate, regimes of spontaneous order already present in social life. Thus, legal rationalization is nothing more than a means to promote accurate encoding of these orders of custom, or "living law." Sometimes they express the role of law more actively, saying that it is a kind of problem-solving technology that responds, or adapts, to "needs" emerging from society. Then the tasks of legal rationalization are to help identify those needs and to improve the adaptive technology. In this century, these views have probably more often been expressed in legal scholarship as a set of vague background assumptions, seemingly too obvious to need any elaboration, than as a full-fledged theory. Blackstone and Adam Smith, both pioneering adaptation theorists, did not shirk the task of trying to spell out in some detail their notions of the adaptive relationship between legal forms and social change, ${ }^{40}$ but despite the inspiration that the work of Maine, Vinogradoff, and Weber ${ }^{41}$ might have provided, their successors have been uninterested, with only rare exceptions, ${ }^{42}$ in trying to develop any systematic social theory of legal change. Thus, when scholars say, as in recent mainstream scholarship they frequently do, ${ }^{43}$

39. See Hale, Considerations Touching the Amendment or Alteration of Lawes, in 1 a Collfction of Tracts Relative to the Law of England 249 (F. Hargrave ed. Dublin 1787). Describing the dangers of "over much hastiness in changing of old lawes, and introducing of new," he writes:

It is most certain, that time and long experience is much more ingenious, subtile and judicious, than all the wisest and acutest wits in the world co-existing can be .... So that in truth antient lawes, especially, that have a common concern, are not the issues of the prudence of this or that council or senate, but they are the production of the various experiences and applications of the wisest thing in the inferior world; to wit, time, which as it discovers day after day new inconveniences, so it doth successively apply new remedies; and indeed it is a kind of aggregation of the discoveries, results and applications of ages and events ....

Id. at 253-54.

40. See 2 W. Blackstone, Commentaries 1 -15 (discussing development of legal institution of property); A. Smith, Lectures on Jurisprudence 13.76, 200.92 (R. Meek, D. Raphael, \& P. Stein eds. 1978) (relating different modes of acquiring property to hunting, pastoral, agricultural, and commercial stages of social development, and relating different forms of government to same stages).

41. See H. Maine, Ancient Law (London 1861); P. Vinogradoff, Outuines of HisToncal JuRISpRUdence (2 vols.) (1920-1922); M. WEBER, EconomY ANd SOCIETY (2 vols.) (G. Roth \& C. Wittich eds. 1968).

42. See notes 134-39 infra (citing recent work of legal scholars in tradition of Weber).

43. Adaptation theory is so pervasive in the scholarship of the past two centuries that it would be a challenge to find work in which it was not present. For representative modern examples of adaptationism, see B. CArbozo, THE Growth of THE LAW (1924), Keeton, Creative Continuity in the Law of Torts, 75 HARv. L. REv. 463, 484 (1962), and pp. 1037-45 infra (discussing legal thought of Whigs and Progressives). 
that law has changed, or should charige, to meet social needs, they do not usually feel that they have to specify what a "social need" is, or how the particular needs they refer to originated and have changed over time. ${ }^{44}$

No matter how loosely they may define their basic concepts, all adaptation theorists must find some way to distinguish adaptive from maladaptive law. The easiest solution to this problem is Hale's and Burke's notion of prescriptive experience, which, in an extreme Panglossian form to which neither Hale nor Burke ever subscribed, holds that whatever law exists is on that account presumptively adaptive. ${ }^{45}$ Though possibly the most coherent of all the adaptation theories, this one has very little charm for legal scholars, who would have nothing to do if it were valid, and who usually want very much to reject some aspects of the present order. Legal scholars frequently ask, when moving toward evaluation, whether legal interventions in social processes follow the natural grain of such processes or artificially cut across it -naturalness, naturally, being adaptive, and artificiality, maladaptive. This move may be made through a procedural theory of institutional competence, a substantive theory of social processes, or some combination of the two.

The procedural theorist asserts at his crudest that some kinds of lawmaking are per se adaptive, others just as automatically maladaptive. In our scholarly tradition, the assignment of these roles has repeatedly switched back and forth between judges and legislatures, though it occasionally gravitates elsewhere, especially to juries and administrative agencies. Adjudication, for instance, has sometimes been thought to be relatively naturally adaptive because case law, being fact-bound, can simply track social custom in the rich particularity of its form in specific controversies, whereas legislation is necessarily general in form and hence abstract. ${ }^{40}$ Alternatively, adjudication is natural because judges possess, through their technical training in case law, vicarious experience of the order of custom, whereas legislators must rely upon the necessarily parochial and limited materials of personal experience or the claims pressed upon them by lobbyists. ${ }^{17}$ Most recently, the ar-

44. Utilitarian legal theory and the current law-and-economics movement have, of course, formulated more or less rigorous theories of the relationship of legal texts to individual wants. But these theories are not, and usually do not pretend to be, social theories, because the social conditions in which preferences arise are treated as exogenous.

45. See J. Pocock, Burke and the Ancient Constitution: A Problem in the History of Ideas, in Politics, Lancuace, and Time 202, 215-28 (1971).

46. See Carter, The Ideal and the Actual in the Law, 13 A.B.A. REr. 217, 231-36 (1890).

47. See Pound, The Economic Interpretation and the Law of Torts, 53 HARv. L. REv. 365,366 (1940). 
gument has surfaced that common law adjudication, for reasons as yet only suspected but having perhaps to do with the survival power of precedents preferred by litigants, ${ }^{48}$ seems to produce economically efficient results, whereas legislation is easily captured by special interests to defeat the immanent rationality of the market. ${ }^{40}$ On the other hand, the simple case for legislative naturalness, if one is willing to equate "social needs" with "the prevailing political consensus of desires," is that legislation is the outcome of majoritarian processes; if one is not so willing, the case is that legislative committees have more time and expertise than judges to inquire deeply into the social order. A more complex case is that legislation better represents the governing coalitions of "minorities rule." The late Alexander Bickel, for example, ascribed Burkean naturalness to the push and pull of the struggles and compromises of corporate interest groups engaged in pluralist political bargaining. With this lush jungly background of striving and decaying organic lives he contrasted the artificial activity of adjudication. Adjudication, he argued, is artificial precisely because of the duty of principled reasoning, which, like any abstractly rational design, if extended beyond its appropriate sphere may have unexpected tragic or ironic consequences to the delicate jungle ecology. ${ }^{50}$

Few people are content, however, to rest adaptation theory entirely on the naturally adaptive processes of any single institution. Hale, our prototype theorist, immediately follows his argument that laws should not be rashly amended (because they are presumptively adapted to spontaneous order) with a list of reasons why they should be prudently amended: ${ }^{51}$ like Burke, he was a reformer. Spontaneous order has a way of becoming very disorderly. Old texts may be carried into new contexts from insufficient litigation or from force of professional habit, so that the emergence of new rules to meet new needs is stunted. Although presumed to be fundamentally sound, any legal system may develop complexities and anomalies that defeat its own ends, but it may be restored to adaptive capacity through moderate reform, that is, through the deployment of some self-consciously rational equilibrating mechanism. With the theory so qualified, all that is needed is a procedural theory of appropriate equilibrating mechanisms. Hale's

48. Priest, The Common Law Process and the Selection of Efficient Rules, $6 \mathrm{~J}$. LEG.AL Stud. 65, 68 (1977). But see Priest, Selective Characteristics of Litigation, 9 J. Lecal STud. 399, 410 (1980) (addition of new variable to model employed in earlier article causes significant revision in conclusions).

49. R. Posner, Economic Anazysis of Law $404-05$ (2d ed. 1977).

50. A. Bickel, The Supreme Court and The IdeA of Progress 173.78 (1970).

51. Hale, supra note 99 , at 264-71. 
own is a common one: see first what may be done through the judiciary and have only last resort to the legislature. ${ }^{52}$ Similarly, if one is a partisan of legislative naturalness, one may advise primary reliance on statutory law-making, subject to correction for gross defect by judicial constitutional review. Most legal writers, of course, have favored multi-tiered systems, in which juries, trial judges, appellate judges, the common-law process, codification by experts, legislation, administration, and judicial review are each given roles both of natural adaptation and of corrective equilibration for different purposes.

To a procedural adaptation theorist, the only valid object of rationalist reform is repair of the natural processes: anything more would be maladaptive intervention. Yet it is a rare scholar who is able to play the game indefinitely-identifying natural mechanisms subject to occasional interruptions for repair by rational ones-without at some point mentioning substantive criteria of adaptability. ${ }^{53}$ Once one has gone so far as to distinguish natural from artificial processes and good from bad reforms, one probably has at least some covert substantive notions of what in social life law should adapt to, and what it should promote, restrain, and avoid. One way to identify natural processes and good reforms is simply to make a list of social needs, as banal as you like-for example, political stability, personal security, or maintaining the market. ${ }^{54}$ Another way is to infer a list of needs from existing law: to hypothesize that every legal text responds to some need, and then simply to guess what that need might be. ${ }^{55}$ However one identifies the needs, the next step is to evaluate how effectively current law serves the need; if it does not, it should be reformed. But this method will get you nowhere without some way to tell current from obsolete needs, since by hypothesis every text responds to some need; what is called for is a theory of social change, or historical direction, that truly adaptive law must follow, and by following which it may be identified. Indeed, the social functionalism of our legal tradition is almost invariably tied to a theory of sociallegal development, generally (with some lapses and variations) a theory

52. Id. at 272.

53. Cf. Brest, The Fundamental Rights Controversy: The Essential Contradictions of Normative Constitutional Scholarship, 90 YALE L.J. 1063, 1104 (1981) (legal theory cannot avoid making substantive choices); Tribe, The Puzzling Persistence of Process-Based Constitutional Theories, 89 YALE L.J. 1063, 1064 (1980) (process approach indeterminate if not informed by theory of substantive rights and values).

54. Surely the longest such list on record is Dean Pound's delineation of individual and societal interests in $3 \mathbf{R}$. Pound, Jurisprudence 25-324 (1959).

55. This "technique" is nothing more than our accustomed method of classroom "policy analysis." 
of progressive development like "modernization," "Whig history," or "legal evolution," which simultaneously licenses most existing law as adaptive and permits historicist criticism of some of it as maladaptively "lagging" behind the course of history. ${ }^{.0}$

This discussion must seem a painfully labored journey to arrive at a familiar destination. I have proceeded this way to emphasize that some notion of historical direction seems to be required by any adaptation theory of law that goes beyond the purely prescriptive. For all their ingenuity in meeting historicist criticism through partial assimilation, however, adaptation theorists actually remain highly vulnerable to it, because the theory's coherence depends on its ability to tell functional from dysfunctional law. This ability can be questioned in several ways.

One attack is the conservative's reductio that the rule claimed to be obsolete may actually be fulfilling a valuable, if latent, social function-for example, Blackstone argued that the bizarre quiddities and fictions of the writ system had freed the English land law from feudal restraints ${ }^{57}$-so that the rule is tampered with at the reformer's peril. The latent function might be precisely that of preserving the authority and legitimacy of the legal system by presenting it to the masses as an historical fait accompli. Once they have the idea of reform, there is no telling what they may do. The usual response is that a little reform will keep them quiet, but that none at all will enrage them. ${ }^{58}$

A non-conservative variant of this attack has been developed by Lawrence Friedman, who argues that all current law, even what looks like anomalous "survivals," exists for a reason and may be explained by reference to some current social reality. If a rule has not changed for a long time, one should ask why not, and one may often find the answer in a deadlock actively brought about by some clash of interest groups. ${ }^{50}$ This perspective absorbs law completely into a determining context by collapsing social "needs" into "interests": law adapts all right, but only to whatever interests happen to get control of it. This view also undermines the normative force of adaptation theory. After all, what could be so wonderful about a law perfectly adapted to the needs of a slave civilization? ${ }^{80}$

56. See pp. 1037-45 infra (discussing theories of Whigs and Progressives).

57. See 3 W. BLACKstone, supra note 40 , at $* 193-97$.

58. See Hay, Properly, Authority, and the Criminal Law, in D. HAY, P. Linebaugh, J. Rule, E. Thompson, \& C. Winslow, Albion's Fatal Tree 17, $24-26$ (1975).

59. See L. Friedman, supre note 11, at 10, 14; Friedman \& Ladinsky, Social Change and the Law of Industrial Accidents, 67 Conum. L. REv. 50, 65, 72, 76 (1967).

60. Austin made this point very effectively against Blackstone's cxaltation of custom: During the Middle Ages, the body of the people, throughout Europe, were in the 
A second attack comes from exacily the opposite direction. Many legal texts cannot be explained, and therefore justified, on the ground that they are functional adaptations: they are chronically maladapted to the manifest functions claimed for them. ${ }^{61}$ Nor may they be explained away as "gaps," "lags," or "anomalies": they have almost never worked the way they are supposed to. ${ }^{62}$ Such texts can be rationalized only as performing latent functions, which destroys the adaptive/maladaptive boundary.

Adaptation theory's dualism between a "society" that has "needs" and a "legal system" that responds to them can also be attacked. Even if one takes adaptationism in its most romantic form, law unconsciously encodes the customary Zeitgeist in a legal text, placing it on the new grid of a professionally interpreted map of texts, and thereby alters its meaning forever. Moreover, by encoding custom, law transmits it to people in other places and times, and thus acts positively to reproduce the custom (in its altered legal form), and not just passively to reflect it. The "society" that keeps throwing up new needs, therefore, is always partly constituted by its laws, which are helping to make the social needs to which the law-makers pretend only to adapt. Pointing out this kind of circularity was a favorite exercise of the Progressive critics of legal formalism. For example, the Supreme Court said that public utility rate-making was confiscatory unless the rate allowed the utility a reasonable return on the fair value of its property, ${ }^{03}$ but of course "fair value" was itself a function of the rate the Court was willing to say was reasonable. ${ }^{04}$

Circularity turned out to be as big a problem for the Progressive jurists, who wanted their law to adapt to the "social facts" of its context instead of to the arid logical consistency worshipped (as they

serf or slavish condition. And this slavish condition of the body of the people originated in custom: Although the imperfect rights which custom gave to their masters, together with the imperfect obligations which custom imposed on thenselves, were afterwards enforced by $L_{2}$ w of which that custom was the basis ....

...

Let us turn our eyes in what direction we may, we shall find that there is no connection between customary law, and the well-being of the many.

$2 \mathrm{~J}$. Austin, supra note 35, at 559-60.

61. See A. Watson, Society and legal Change 7-8, 130-37 (1977). In this very interesting book, Watson accepts the basic tenet of adaptation theory that societies have needs to which their laws should respond, but says that legal systems chronically lag behind such needs, copiously illustrating this claim with examples from Roman and English law.

62. See pp. 1022-23 supra (discussing demonstrations of discontinuity between texts and contexts).

63. See Smyth v. Ames, 169 U.S. 466, 526, 546.47, decree modified, 171 U.S. 361 (1898).

64. See J. Dickinson, Administrative Justice and the Supremacy of LAW in the UNITED STATES 221-26 (1927). 
thought) by their predecessors. Yet the "facts" as stated in a case or in a legislative history that describes the social situation to which the legal text is to respond are also in part artifacts of the legal system. If the story were differently told, it would suggest different solutions. ${ }^{.5}$ The critic can further generalize the point, showing how legal texts participate in the construction of the social world, populating it with creatures of law's own devising, abstract self-determining individuals and artificial corporate persons, ascribing "interests" to them and deciding when their sufferings are recognizable "harms."

This last line of criticism suggests a fourth. The social needs usually postulated, besides being partly a construct of the legal system rather than somehow objectively present in society apart from law, are frequently in contradiction with one another. ${ }^{67}$ For example, American lawyers of the nineteenth century liked to assert that a main function of law was to protect security in possession and certainty in exchange at the same time that it fostered capital accumulation; they found in practice, however, that they had constantly to choose among these purposes, so that the actual social need served was that of mediating these conflicts by dressing up doctrinal formulae in traditional language to obscure the fact that some people's security and certainty were being promoted at the expense of others' ${ }^{68}$ Interestingly, like other latent functions, this important one is given scant attention in the ordinary scholarly literature.

Finally, the critic can attack the assumptions about the course of history underlying adaptation theory. She can, for example, show that the directional histories are simply wrong. The assumptions of the evolutionary histories of nineteenth-century jurists, especially the assumptions of necessary stage developments in all-at least all "progressive"-societies from communalism toward individualism, and status to contract, were, as Peter Stein has recently reminded us, ${ }^{68}$ broken

65. See, e.g., Danzig, How Questions Begot Answers in Felix Frankfurter's First Flag Salute Opinion, 1977 SUP. Cr. REv. 257, 258 (1978) (Justice Frankfurter reached opposite conclusions in similar cases by "differential focusing"). An excellent recent treatment of "fact-skepticism" is found in Casebeer, The Judging Glass, 33 Minm L. REv. 59, 98-118 (1978).

66. See, e.g., A. NékאM, The Personality Conceltion of the Legal Entity 116-24 (1938); J. Noonan, Persons and Masks of the Law 14-25 (1976); J. Vining, Legal IdenTITY 20-33 (1978); Kelman, Consumption Theory, Production Theory, and Ideology in the Coase Theorem, 52 S. CAL. L. REv. 669, 695-96 (1979).

67. This argument is generalized in Kennedy, The Structure of Blackstone's Commentaries, 28 Bufralo L. Rev. 209, $354-72$ (1979).

68. See, e.g., M. Horwitz, The Transformation of American Law, 1780.1860, at 31 62 (1977); Scheiber, Property Law, Expropriation, and Resource Allocation by Government: the United States, 1789-1910, 33 J. EcoN. Hist. 232, 240.43 (1973).

69. P. Stein, Legar Evolution 107-21 (1980). This book might have been entitled $A$ brief and lucid history of adaptation theory in nineteenth century England. 
up by historicist critics who found that even English legal development had skipped stages or gone through them in reverse order!70

I have given a lot of attention to adaptation theory because under one name or another-expediency, convenience, utility, growth, development, modernization, historical or sociological jurisprudence, the functional approach, social engineering, policy analysis, efficiency, or responsive law-it has been a component of virtually all the majo" movements of Anglo-American juristic writing, and has been a common element cutting across otherwise violent controversies between schools. That is, the idea that law is good if it dynamically adapts to social change is the same idea whether the writer gives primary emphasis to naturally adaptive procedures or to consciously adaptive equilibrating mechanisms; it is also, I believe, vulnerable to the same criticisms. Even theories that at first sight look like pure denial, claiming that legal rationality is not historically contingent, often turn out to be historicist adaptationism in disguise. The idea that the purpose of law is to realize in society certain universally valid norms is often tied to a notion of historical development by which the good norms -individual liberty against the state, political equality, freedom of contract, or mixed government, for example-are known to be good because they have been gradually and progressively realizing themselves in history, or because they have been evolving into their present highly developed forms from inferior ones. ${ }^{71}$ The idea that law should adapt to follow or promote its dynamically unfolding normative context does not seem to me essentially different from the ideal of adaptation to social context.

Resignation. The last of the responsive modes, resignation, is not really a theory but a set of attitudes. Legal rationality, say the resigned, is only an existential affirmation of order in the midst of nothingness. It satisfies human cravings for meaning and it nourishes myths bolstering the (impliedly necessary and desirable) cohesion of society or the authority of the state. In weaker versions, the resigned admit that legal institutions, like all human works, are naturally imperfect, are always, because of historical contingency, out-of-date, and are inevitably, because of social complexity, problematic in their effects; but that's life. In yet another version, the concession is that all our rationalizing activity is tentative and provisional, all our ideas of the good possibly parochial, but the best that we happen to know.

70. See 1 F. Pollock \& F. Maitzand, The History of English LAw 627-34, 654-57, 670.88 (1895) (discussing the "individualism" of early English village communities).

71. See, e.g., Ames, Law and Morals, 22 Harv. L. Rev. 97, 113 (1908) (law has developed through six centuries toward closer "harmony with moral principles"). 
No very definite or systematic patterns are likely to emerge from our inquiries, so we must be content to work out the seemingly pragmatic best solutions case by case.

This attitude is extraordinarily difficult to isolate for discussion because, like denial, it is hardly ever found in pure form, although it is pervasively sprinkled through legal writing ${ }^{72}$ and is more of a mood, or tone of voice, than anything one can really grasp. Its strangeness is that while seeming in every way to concede the historicist critics' case, its actual deployment is to justify the orthodox practice of mainstream rationalizing rather than to incorporate the critics' perspective. The effect is like a move in judo: the resigned scholar uses the critics' strength to flip them on their backs and meanwhile keeps doing what he did before. But why, if he recognizes the limitations of his methods? If he sees that current norms and practices are historically contingent, why does he continue writing as if they were natural and necessary? If he is perfectly aware, as he claims he is, that law rarely really works the way it is supposed to, why does he continue to contribute to a style of rationalizing scholarship that accepts at face value an idealized instrumental view of the role of law in society? More generally, if our conventional styles of rationalization are compelled neither by suprahistorical norms nor by the logic of history-nor even by a Cartesian model around which the discipline is organized-why don't we do something else?

\section{The Persistence of Old Modes: Whigs and Progressives}

We don't, though. The old modes persist. One way to read the history of our legal thought is as a succession of mixings of the main responsive modes into-"paradigms" is too pretentious, "systems" too suggestive of system-amalgams that command the allegiance of most of the orthodox until they come under attack and are demolished by historicist criticism, among other kinds. But such criticism is strictly limited in its impact by the regrouping, like white cells, of the same old responsive modes into another amalgam uncannily like the one recently demolished.

Let me try briefly to illustrate how this process has worked through a summary account of how the amalgam put together by American antebellum legal writers came under historicist fire around the beginning of our own century, and was then replaced by another and similar amalgam that has dominated our scholarship until very recently.

72. Resignation occasionally surfaces as the dominant mood in the work of some writers-for example, Holmes, Thurman Arnold, and, more recently, Calvin Woodard and Grant Gilmore. 
The principal contributors to whit Morton Horwitz has called the "treatise tradition," 73 the early nineteenth century's closest analogue to modern legal scholarship, were an elite of primarily Federalist and Whig lawyers ${ }^{74}$ anxious to vindicate an ambitious conception of their political role in the new American republic. This role was linked to the enlarged importance of the judiciary in the Federalist scheme, by which the people had delegated governmental authority not simply to representative assemblies but to a complexly interacting system of separated powers, the functioning of each of which was critical to the scheme as a whole. As a result, the state and federal judiciaries, through their authority to say what the law was, were able to claim and to acquire the authority to interpret the fundamental law of the constitutions. ${ }^{75}$ Moreover, partly by default of available alternatives, partly by astute political suppression of alternatives occasionally proposed, the profession was able to secure to the federal and state judiciaries, assisted by a learned elite of leaders of their respective bars, the principal responsibility for expounding and developing an American law of private rights. ${ }^{70}$ To justify their maintaining this position, these judges and lawyers appealed to their command of a body of legal learning and techniques for working with it ("legal science") that, they said, could guarantee liberty and property far more reliably than its competitors, the temporary whimsies of factional legislative coalitions or the untutored non-lawyer's intuitions about natural rights.

A potential embarrassment to this claim lay in the fact that English law was the chief component of traditional legal learning. The Revolution had transformed this law into an alien system and one vulnerable to the savage historicist criticism that it was honeycombed by the feudal and superstitious corruptions of centuries, of which, despite progress, "much of the domineering spirit" 77 still remained. Feeling obliged to disentangle their science from its disreputable past while preserving its traditional authority, the Whig-Federalist lawyers deployed against their historicist and natural-rights critics a dazzling array of responsive modes.

73. See M. Horwirz, stpra note 68 , at $257-58$ (contributors to this tradition included Chancellor Kent, Joseph Story, and Joseph Angell).

74. Joseph Story is included in this category, see note 73 supra, although of course he started his career as a Jeffersonian.

75. See G. Woon, supra note 9, at 453-63.

76. Radical reformers in Pennsylvania, for example, "denounced the legal profession, the common law, and the idea of an independent judiciary." $R$. Euls, The Jeffersonian Crists 16I-64 (1971). Nevertheless, the bar was able to preserve the judiciary's role. See G. Gawalt, The Promise of Power 81-118 (1979).

77. J. Adams, $A$ dissertation on the Canon and the Feudal Law, in 1 PApers of JohN ADAMs 103, 127 (R. Taylor, M. Kline, \& G. Lint eds. 1977). 
One, a denial on which they could expect general agreement, was the response that the common law contained certain suprahistorical principles of fundamental law-either the immemorial norms of the ancient Gothic constitution as finally revindicated through historical struggle or simply principles expressive of the law of nature ${ }^{78}-$ which Americans had asserted as their birthright in the Revolution and whose best guarantee was adoption of a system known to contain them. This position was undercut somewhat by the elevation of the best known of these principles into written constitutions and bills of rights.

The modes that turned out to be most useful were the several varieties of adaptationism. One was prescriptive adaptationism, the argument that the common law was a vast Hale-like repository of collective experience about what ordinary people and wise judges have thought to be useful customs and norms in concrete circumstances. ${ }^{79}$ A second was procedural adaptationism-judge-made case law had the flexibility to change with changing circumstances. This mode was accompanied by a dash of resignation. Because human actions were infinite in their variety and constantly in flux, and legal texts were constantly changing their meaning in new contexts, it was futile and vain to hope to achieve certainty in the law by capturing a rule in a legislative phrase or code. Yet this argument for the constant necessity of reinterpreting texts did not remain a pessimistic one about the indeterminacy of legal language; it quickly became an affirmative argument in favor of entrusting the job of reinterpretation to those specially trained in the science of finding the one "true sense," in the new context, of the old text. ${ }^{80}$ Third, the Whig-Federalist lawyers had resort to equilibrating mechanisms. Lawyers conceded over and over again to their critics that the common law was full of feudal excrescences, silly fictions, and parochially English customs and inventions. But Americans, implicitly at the beginning of the colonial settlements and explicitly by the terms of the "reception" statutes, had adopted the common law only insofar as it met their needs and conditions, ${ }^{81}$ giving a valuable discretion to their judges to dispense with

78. See G. WoOD, supra note 9, at 9-10 (discussing the blending of the ideas that common-law rights were justified because they had "existed from time immemorial" and because they embodied natural law).

79. See J. Wilson, Lectures on Law, in 1 Works of JAmes Wilson 204-07 (Philadelphia 1804), for a typical rhapsody in this key.

80. See F. Lieber, Legal and Political Hermeneutics 86 (enlarged ed. Boston 1839).

81. See Van Ness v. Pacard, 27 U.S. (2 Pet.) 137, 144-45 (1829) (Story, J.) (court should not assume, absent authoritative state ruling, that state law includes common-law doctrine that fixtures become part of freehold, because doctrine might have proven not ap. plicable to wilderness conditions); M. HoRwirz, supra note 68, at 24-27. 
or vary English precedent. Furthern:ore, the response continued, England herself had shown what could be accomplished by way of judicial reform, through the example of Lord Mansfield's selective importation of international commercial law, and more recent judges' use of European civilian writers, to "expand with the exigencies of society," and to suit the "business of a nation increasing in wealth and commerce, and connecting itself with the interests of all the world."82 Evolutionary adaptation was a fourth mode. Despite all its historical archaisms and positive abuses maladaptively implanted during corrupt regimes, the long-term trend of the common law had been a progressive development-for example, away from feudal restraints on alienation, toward a liberal commercial policy ${ }^{83}$-in directions entirely compatible with American republicanism.

By these means and others, legal science was related to something more fundamental than mere politics: to principles of fundamental right as realized teleologically through historical experience and, even more important, to needs spontaneously emerging from social life and to the long-term logic of historical development.

The jurists who put together the "formalist" or "classical" legal schemes of the late nineteenth century did not materially differ in ambitions or assumptions from their antebellum predecessors, though of course their methods were very much more systematic. They believed that the common law had gradually been ridding itself of the archaisms and anomalies preventing its systematization, and was now at the point where, with appropriate rationalizing attention from scholars and law reformers, more and more of its parts might be subsumed under principles of ever greater generality. ${ }^{84}$ In other words, pushed along by scientific lawyers, the common law had been evolving toward ever-increasing generality and internal consistency, creating as it did so an ever larger scope for individual autonomy. Thus, in most cases historical study of the origins and development of a legal rule, which should reveal the relation of that rule to an enduring principle (or else that, having no such relation, the rule was only an anachronistic

82. J. Story, Growth of the Commercial Law, in Miscellaneous Writings of Joseph STORY 262, 279 (W. Story ed. Boston 1852).

83. See, e.g., 3 J. Kent, Commentaries on AMERICAN LAw 401-13 (New York 1828) (tracing evolution from feudal to allodial estates in land); 4 id. at 433-37 (New York 1830) (tracing development of free alienability of land).

84. See, e.g., J. Diklon, The Laws and Jurisprudence of England and America $316-89$ (1894); Ames, supra note 71, at 103, 113; cf. Holmes, Codes, and the Arrangement of the Law, 5 AM. L. REv. 1, 1-2 (1870) (proposing a system for classification and codification of common law that would inform law's future development). 
survival), should be a method complementary to analytic derivation of the rule from a principle; they should arrive at the same result. ${ }^{85}$ Where the results did not coincide, the historical version should be sacrificed, usually on the grounds that it resulted from a textual misreading by some judges in the chain, which had interfered with its proper evolutionary course, and that clarity and certainty in the analytic system required its excision. In this way the apparently Cartesian abstraction of classical legal science could be seen as responsive both to the current social need for precise definitions of the scope and limits of autonomous conduct and to the long-run course of history.

Hence the classical scheme made itself vulnerable to historicist attack. The main features of the attack are familiar enough not to require more than a quick summary: ${ }^{80}$ (1) The model of evolution from "status to contract" underlying classical-legal individualism was oversimplified and distorted. (2) Even if it were correct, evolution had not stopped; if England were taken as the model, modern societies had left individualism behind and entered a new stage of "collectivism." 87 (3) Moreover, said Holmes, giving evolutionism a new Darwinian twist, there is no reason why the struggle to survive should not take the form of a struggle to capture the state and make it legislate in one's favor. Judicial intervention while the struggle continues is an arbitrary taking of sides because truly adaptive law can come about only when the winners are clear. ${ }^{88}$ (4) The norms that classical jurists assert as absolute principles immanent in the law are in fact only specific and rather parochial ideologies of certain elites. ("The Fourteenth Amendment does not enact Mr. Herbert Spencer's Social Statics." ${ }^{82}$ ) (5) The formalist scheme is dysfunctional because it tries to freeze these ideologies in the law, while social development requires the recognition of new needs. ${ }^{20}(6)$ The scheme is totally nonfunctional

85. Ames's work typifies the combined historic-analytic method as practiced by a master. See, e.g., J. AMEs, Two Theories of Consideration, in Lectures ON LEGAL History 323 (1913); J. Ames, The Doctrine of Price v. Neal, in Lectures on Legal History 270, 284 (1913).

86. See pp. 1027-28 supra.

87. See A. Dicey, Lectures on the Relation Between law \& Public Opinion in England During the Nineteenth Century 299-301 (1905).

88. See Vegelahn v. Guntner, 167 Mass. 92, 105.06, 44 N.E. 1077, 1080 (1896) (Holmes, J., dissenting); O. Holmes, Law and the Court, in Colnected Legar Papers 291, 294.95 (1920).

89. Lochner v. New York, 198 U.S. 45, 75-76 (1905) (Holmes, J., dissenting).

90. See Pound, Liberly of Contract, 18 YALE L.J. 454, 454 (1909) (in holding that liberty of contract is infringed by any legislation that disrupts the equal rights of employers and employees, the courts persisted in applying "an academic theory of equality in the face of practical conditions of inequality'). 
because its abstract formulations ca? be manipulated to serve any interest whatever. ${ }^{91}$

Implicit, of course, in all these criticisms was an emerging theory of genuinely adaptive law. Indeed, when this critical generation of "Progressives" came to build their own amalgam, most of its emphasis was on adaptation. In Progressive theory, speaking very generally, social needs assert themselves through "interests." 92 Interests are the desires of individuals, but also the programs or aims of concrete social groups in particular relations (bankrupts and creditors, consumers and manufacturers, union members and employers, small stockholders and management) as well as the generally shared purposes of the society as a whole. Interests conflict. The object of law, then, is to ascertain what interests exist, to decide which ones deserve recognition, and to achieve an efficient adjustment of them, approximating their ideal harmonization in the "public interest." Unlike the formalists, who sought to restrict all lawmaking agencies within carefully bounded spheres, the Progressives had no fixed institutional notion of adaptation, preferring to allocate the workload according to perceived competence to adapt because of expertise, enforcement capability, and so forth. While presuming as an initial matter that when the legislature speaks it is adequately harmonizing interests, they also designed an active adaptive role for courts, both as trackers of custom and as social engineers.

Of special interest to our topic are the ways in which the Progressive scholars, sometimes through exceptionally distinguished historical work, located their own enterprise in time. Pound and Llewellyn, for example, saw twentieth century judicial method as a continuation of the "Grand Style" of the antebellum "Formative Era," when the courts had brilliantly adapted the old common law to novel social and economic needs. ${ }^{93}$ Hurst, Hartz, and the Handlins (only the first strictly speaking a legal scholar) discovered a history of extensive state promotion and regulation of the economy through legislative and administrative as well as judicial action, ${ }^{84}$ so that the New Deal, in perspective, could be seen as the culmination of an American tradition

91. See, e.g., Smith, Legal Cause in Actions of Tort (pt. 1), 25 Harv. L. REv. 103, 106-28 (1911) (manipulating traditional tests of causality in tort).

92. "Interest" theory in Progressive thought was given its most thorough and abstract treatment by Roscoe Pound. See 3 R. Pound, supra note 54, at 15-24.

93. See K. Llewellyn, The Common Law Tradition 36-37 (1960); R. Pound, The Formative ERA of American Law 93-94 (1938).

94. See O. Handin \& M. Handin, Commonwealth 254-63 (1947); L. Hartz, Economic Policy and Democratic Thought 289-320 (1948); J. Hurst, Law and the ConDITIONS OF FREEDOM 33-70 (1956). 
of pragmatic response to social needs, without excessive fussing about ideological laissez-faire. All of this work relied upon an implicit or explicit Weberian view of the relationship of law to the social order. The legal system had provided valuable and possibly indispensable institutional support to the development of American capitalism, chiefly through the adoption of legal forms that promoted capital formation, the security of exchange, and demolition of barriers to the interstate mobility of capital and property, and through the development of liability rules that favored dynamic entrepreneurs over static rentier interests.

But if antebellum law had been adaptive, the Progressive generation agreed, the law of their late nineteenth and twentieth century predecessors was woefully maladaptive. Harsh liability rules such as the fellow-servant rule, or policies favoring unrestricted accumulation, might have been necessary in the period of industrial takeoff, but these ways of thinking had hardened into dogma, inhibiting reform through legislative or administrative equilibration that could have dealt creatively with the social consequences of organized capitalism. There was a lag; the legal system was mired in immobility or, less kindly, captured by private interests. Lochner v. New York ${ }^{05}$ symbolized the historical low point: it is the counterpart, in the Progressive view, of the old Whigs' Stuart despotism or the corruption of the Walpole ministry. For judicial passivists, the evil was that judges had the nerve to make social policy with broad implications; for activists, that the policy made was maladaptive, out of tune with the course of social development.

The process of historicizing continues, however, so that the Progressive view has suffered some recent shocks, which are exemplified by work on the narrow subject of the Progressive interpretation of history: Lawrence Friedman has restated the entire history of the nineteenth century as one of interests-determined law. Before the Civil War, a broad spectrum of interests united in wanting a law that facilitated business, and got it. In the later period, these interests had to contend with others at cross-purposes. The law was neither more nor less adaptive later than earlier; it simply reflected different constellations of interests. ${ }^{\circ 6}$ In the other major modern synthesis,

95. 198 U.S. 45 (1905).

96. A legal system must respond to the needs of its time and its society. When one speaks of a legal system as out of tune with its society, one is usually referring to quite a different phenomenon: a conflict between parts of society or specific interest groups in which the legal system, or some specialized institution, responds to or reflects some interests but not others. To state, for example, that judges of the 
Morton Horwitz accepts the Progr sssive view of the active role of the state and law in antebellum society, but argues that the social functions served were expropriation on behalf of entrepreneurs and protection of their profits from redistribution. ${ }^{97}$ In a sense, Horwitz remains within the Progressive tradition in that he presents the republican idea of a government serving all its citizens as betrayed (by lawyers among others) to commercial interests; he departs from it in locating the betrayal at the beginning, rather than the end, of the nineteenth century. With one version or another of the thesis that legal regulatory processes were captured by or designed to favor the regulated,98 revisionists of both right and left have challenged the Progressives' optimistic conclusion that they reclaimed the law from exclusive service to special interests for the ideally adaptive maximizing of everyone's interest. At the same time, the Progressives' picture of late nineteenth century law is being slowly painted over. Posner has sought to vindicate the period's devotion to negligence as the basis of tort liability;09 and McCurdy, Kennedy, and Atiyah, among others, by taking legal "formalism" seriously on its own terms as a rationalizing enterprise, have made possible an understanding of it as a formidably plausible ideological construct for its time, rather than simply as a vast collective misguidedness or corruption..$^{100}$

Under these and similar shocks, the Progressive amalgam's long domination over the organization of scholarly thinking about law is breaking up, and nothing comparable is in prospect to replace it. Legal scholars can still be found who write in all the traditional responsive modes, but no new amalgam seems to be crystallizing. Perhaps this is because law teachers have been recruited from a much broader

late nineteenth century who issued labor injunctions and voided welfare legislation were out of step with their society or unresponsive to social needs is simply to take the victor's view of history. These judges were out of step with a growing, powerful social movement; but their decisions were enunciated in cases brought or defended by real litigants with real economic and social interests.

Friedman, Heart Against Head: Perry Miller and the Legal Mind (Book Review), 77

YALE L.J. 1244, 1255 (1968). See generally L. FrIEDMAN, supra note 11.

97. M. HoRwitz, supra note 68 , at 99-102.

98. See McCraw, Regulation in America: A Review Article, 49 Bus. Hist. Rev. 159, 164-79 (1975) (surveying shifting views of regulation among economists, lawyers, historians, and political scientists).

99. Posner, $A$ Theory of Negligence, 1 J. Legal Stud. 29, 29 (1972) (proposing a theory, based on a sample of American court decisions from the period 1875-1905, of the social function of the fault system of accident liability).

100. See, e.g., P. Atiyah, The Rise and Fall of Freedom of Contract 388-97 (1979); Kennedy, Form and Substance in Private Law Adjudication, 89 HaRv. L. REv. 1685, 1728-31, 1746.48 (1976); McCurdy, Justice Field and the Jurisprudence of Government-Business Relations: Some Parameters of Laissez-Faire Constitutionalism, 1863-1897, 61 J. AM. Hist. 970, $1004-05$ (1975). 
political spectrum than ever before, even in the 1930s; perhaps it is also because scholars with totally incompatible intellectual stances have sharpened their weapons against one another.

\section{Some Conclusions}

In this delightfully heterodox climate there is reason to hope that our mainstream legal scholarship will at last move beyond its standard modes of responding to historicist assertions of the social contingency of law and legal rationalization. Doubtless, there are no solutions to the problems, but the modes as they have been practiced have inhibited the development of more interesting responses, calling forth in their turn new criticisms, and so onward in a dialogue lifted clear of the old gravitational field. Of course, there is also the risk, a serious one if the historical experience is any guide, that the pull of the old field will be too strong, so that attempts to break clear will be ignored or defeated by misunderstanding. The idea behind this article is that this risk may be avoided if one can identify some of the points of impasse at which the dialogue has traditionally become stuck. Let me conclude by pointing to some examples of how the dialogue is impoverished by sticking at those points, and of how much it could gain by becoming unstuck.

Denial again. Unvarnished denials of the historicity of legal reasoning, for instance, are uninteresting contributions to the dialogue precisely because they deny there is a problem. Take for example a very recent addition to the literature of denial by Richard Epstein, ${ }^{101}$ exemplary for the brilliance and baldness with which it puts the case for the universality of basic legal principles. His article's strength is its useful attack on shallow versions of the adaptationist idea that law should change with changing circumstances, such as the notion that we have gone from fault to strict liability in tort in order to adapt to technological change. To this assertion, Epstein says truly, in relevant respects circumstances have not changed in the past century. ${ }^{102} \mathrm{He}$ admits some kinds of social change might affect the validity of principles expressed in a legal text: changing customs might change the meaning of agreement, changing background regimes of public law

101. Epstein, The Static Conception of the Common Law, 9 J. Lrgal STud. 253 (1980).

102. He does not, however, have an explanation of his own for why rationales for liability have changed as they have. Indeed, one of the problems with denial theory generally is that its adherents must 2ssert that entire societies, for whole epochs, just get things wrong and adopt false ideas, but they have no way of making intelligible why that should happen. 
might change the need for or impict of a rule of private law, and changing values might change the analysis of the relative costs and benefits of different activities. ${ }^{103}$ All other types of change are ruled trivial. Whereas Romans inflicted harms with poisons, we do it with automobiles, ${ }^{104}$ but their principles of liability are the same as ours.

Though unusually breathtaking in the confidence with which it asserts the existence of history-independent legal principles, the article is typical of the standard denial mode in ignoring the problems of the historicity of consciousness itself. Epstein claims that we could profitably discuss tort liability with a Roman lawyer. What could we talk about? Superficially, perhaps quite a lot. We seem to have a common problem, the infliction and compensation of harms, and (along with Holmes's $\operatorname{dog}^{103}$ ) a common perception that intentional are worse than carelessly or accidentally inflicted harms. Even at this level of very great generality, however, our ability to exchange ideas depends on much more than our sharing and attempting to realize some universal moral propositions, such as comparable ideas of property, injuries to it, and compensation systems, all declared in a rational general form, and enforced by a separate legal system. Of course, in the case of tort, we happen to have still more in common, an impressively large and detailed stock of categories of classification and conventional modes of discourse, because since the twelfth century, with increasing intensity in the nineteenth, legal scholars have made a determined effort to resurrect the Roman categories and appropriate them to modern use. To the extent we think the same way, it is surely in part because we have tried so hard to do so. The taking of a similarity grounded in deliberate cultural appropriation for the common recognition of a universal norm is circularity with a vengeance.

Of course, this borrowing does not mean that the set of norms is not universally valid. As Charles Fried would undoubtedly say, maybe we appropriated the Roman norms because they were the right ones. ${ }^{108}$

103. Id. at $266-69$.

104. Id. at 259-60.

105. See O. Holmes, The Common LAw 3 (1881) (“[E]ven a dog distinguishes between being stumbled over and being kicked.")

106. In the same symposium issue in which Epstein's article appears, Fried produces a novel (at least to me) form of denial theory that seeks to account for changes in legal texts by some means other than reference to their contexts. If I read him correctly, he says that law changes when people are persuaded to change it by morally correct arguments, so that the best way to explain why an argument was accepted is to ask whether it was true. If one accepts Fried's premise that there is some suprahistorical means of assessing the moral correctness of, say, arguments on points of medieval land law, and his qualification that this is not a theory of moral progress because bad arguments may persist for a long time (and may even be dominant now), the theory is unassailable from 
The trouble here lies in supposing that, because in some formulations their texts can be lifted word for word from their context and still make sense in ours, our norms are theirs. Consider one of Epstein's examples of the proposition that "justifications [of legal rules] are essentially independent of social changes": "In the law of contracts, a promisee who uses force or fraud cannot demand performance of the promise exacted from his promisor." 107 If the other system has a "law" of "contracts" recognizing and enforcing abstract promises subject to abstractly defined defenses, we can be confident of many basic similarities between its universe of concepts and ours. Even this confidence, however, may be premature. On being asked, "why do your laws enforce this promise?" lawyers in the other system might say, "because it was sworn under a banyan tree by the promisee's wife's brother." Ours might say, "in order to support the functioning of the market," an answer quite as mysterious to a world that is familiar with exchange transactions but has no concept of an "economy" as is the banyan-oath to ours. ${ }^{108}$ So too with force and fraud: any exchange of promises may be regarded as one of mutual threats to withhold performance unless the other side comes across. ${ }^{109}$

Surely what one wants to know about another system is how it draws the line between the voluntary and the coerced exchange, because only by knowing that can one get a sense of the operational meanings it gives to the notions of freedom and coercion. Knowing that it expresses the general norms is about as useful as learning that a nation calls itself a "people's democratic republic."110 Leon Litwack has re-

the historicist perspective. If all that he is saying is that lawmakers usually believe in what they are doing, and may be convinced to do something different by an argument that is persuasive in the terms of their moral universe, his claim seems unexceptionable. But the way to vindicate that thesis would be the historical attempt at reconstruction of the lawmakers' moral universe, a necessary first step, it would seem, even for someone who thinks as Fried apparently does that their universe's terms may be translated point for point into some universal moral scheme of reference. See Fried, The Laws of Change: The Cumning of Reason in Moral and Legal History, 9 J. LEGAL STud. 335, $336-39$ (1980).

107. Epstein, supra note 101, at 256.

108. See M. FinLey, THE ANCient Economy $17-23$ (1973) (modern economic concepts and models not applicable to study of ancient economy); K. Polanyi, Aristotle Discovers the Econoiny, in Primitive, Archaic, AND Modern Economies 78, 84-86 (1968) (pre-modern communities have no integrated concept of an "economy"). For a contrary view, see Posner's characteristically sweeping argument, based on extensive reading in anthropological literatures, in Posner, $A$ Theory of Primitive Society, with Special Reference to Primitive Law, 23 J.L. \& EcoN. 1, 2, 4-5 (1980) (explaining customs and institutions of primitive society as economically rational adaptations to high information costs and criticizing "excessively narrow view of what is economic").

109. See Hale, Bargaining, Duress, and Economic Liberty, 43 Colum. L. REv. 603, 604 (1943).

110. Of course, even an interpreter with a fairly full catalogue of instances of ap. plications of the norms may be seriously misled. A scheme of legal norms that narrow- 
cently shown us how, in the Reconstruction South, the idea of "contract" with its happy connotations of free and mutual bargaining was put to work to subject newly emancipated slaves to regimes of domination even worse than their former conditions of servitude. ${ }^{111}$ Likewise, "property," with all its associations of the legal watch set about home and hearth, may be used to protect an owner's security or help him express his personality; it may also enable him to exclude others from what they need except on the condition that they submit to his power. 112 By now we are surely accustomed to the idea that "freedom of contract" and "duress" are concepts with such extraordinary historical and cultural pliability that their meanings can be plausibly expounded only at a level of great particularity. ${ }^{113}$ If we take just the words, we are likely to become involved in absurd mistranslations-to say "free contract," for example, where, if we knew the context, we would be more likely to say "peonage."

At this stage one listens for the accusation of "Relativist!," but it is really beside the point. One does not have to be a relativist to doubt that our legal principles are universal simply because other places and times have used conceptual language sounding rather like our own. One is merely asserting that on closer investigation the resemblance will come to appear superficial, and that anyone who seriously claims that there are normative universals must try to reconstruct the language in which the old text is embedded in sufficient detail to support a theory that something in the old text is comparable to something in the new. ${ }^{114}$ The alternatives are almost certainly parochialism (taking the norms we happen to be used to as the universals), banality (positing as universals a list of uselessly general and abstract values), or mistranslation.

Some people would deny that even this more careful reconstruction of other idea systems will make comparisons possible-either on the

ly restricts the scope of duties owed to others is one thing in a society that also has strongly sanctioned norms of charitable duties-in such a society, legal restrictions are only limitations on jurisdiction, not definitive statements about right behavior-and quite another thing in a society where religious norms have atrophied.

111. L. Litwack, BeEn IN THE Storm So LONG 408-20 (1979).

112. The most systematic treatment of this idea is found in $\mathbf{K}$. ReNnER, The INSTItutions of Private Law $104-58$ (1949).

113. See Dawson, Economic Duress-An Essay in Perspective, 45 Mich. L. Rev. 253, 288.89 (1947).

114. Cf. O. Holmes, The Path of the Law, in Collected Leas Papers 167, 197.98 (1920):

I assume that, if it is well to study the Roman Law, it is well to study it as a working system. That means mastering a set of technicalities more difficult and less well understood than our own, and studying another course of history by which even more than our own the Roman law must be explained. 
ground that the other legal ideas have meaning only in the terms of their own contexts, so are not transferable to others, or on the ground that reconstruction of the other system is futile because we can only approach the task with our own apparatus of concepts, ${ }^{115}$ and there is no theory-independent conceptual language into which both our own and the other system may be translated for comparative purposes. ${ }^{116}$ As Maitland put it:

If we speak, we must speak with words; if we think, we must think with thoughts. We are moderns and our words and thoughts can not but be modern. Perhaps . . . it is too late for us to be early English. Every thought will be too sharp, every word will imply too many contrasts. ${ }^{117}$

Others would maintain to the contrary that uncovering the structures deeply underlying all conceptual schemes is possible. I am not taking a position on this controversy because my point is the much more limited one that nobody is going to get very far in meeting the threat of historical contingency by the more elementary denials that it is a problem. And one is cutting oneself off from the prospect of realizing a greatly enriched understanding of one's own system of norms by examining it in comparison with what appear to be very different ones, the first step in that process of comparison being the attempt, doomed though it may be, at reconstructing other systems.

The process of reconstruction may end up convincing us that the other systems-the conceptual world of our Constitution-makers, for example-is indeed discontinuous and unrecapturable. Even this discovery would not have made the effort useless; we would at least have learned, as Brest and Ely have tried to teach us, ${ }^{118}$ the folly of a literalistic interpretation. And one could learn as well through the contrast. One of the aims of the recent work of Morton Horwitz, William Nelson, and John Reid ${ }^{110}$ has been to identify the characteristics of "modern" law (which they severally describe as instrumentalism, adjusting the claims of atomized individuals and interest groups, and law-as-command) by reference to what they see as the "pre-modern" law of the eighteenth century. ${ }^{120}$ But reconstruction might do more

115. See P. Winch, The Idea of A Social science and Its Relation to Philosophy 86-91 (1958).

116. See R. Rorty, Philosophy and the Mirror or NAtURE 315.94 (1979).

117. F. MAITLAND, TOWNSHIP AND BOROUGH 22 (1898).

118. See p. 1020 supra.

119. See M. Horwitz, supra note 68, at 16-30; W. Nerson, Americanization of the Common LAW 173.74 (1975); J. REID, supra note 17, at 128.

120. Hendrik Hartog pointed out this similarity to me. 
for us than that: it might demonstrate an actual continuity between the old system and our own. This continuity might be evolutionary, as was assumed by all the nineteenth-century theories of legal progress, but might also be something much more interesting, a relationship of structural analogy such as anthropologists have found, for instance, between pre-scientific and scientific thought. ${ }^{121}$ To give an example or two: Douglas Hay's deservedly celebrated essay on Property, Authority, and the Criminal Law, ${ }^{122}$ which showed the repressive advantages gained when eighteenth-century criminal law combined a paper regime of rarely enforced but terrifying sanctions with an enforcement regime of merciful discretion, abundantly produces insights into modern law, not only modern criminal justice administration but any discretionary administration of a formal system: substitute "street-level bureaucrats" or "political machine" for Hay's "country gentry."

Just lately there has been emerging a remarkable literature on the theme of representation: how our law constitutes artificial entities (abstract individuals, classes of litigants, corporations, states) to represent real persons, then finds real persons to represent the entities thus constituted; also how the law refuses to recognize some persons and collectivities as capable of representing or being represented for some purposes. This theme has been explored in such diverse legal contexts as those of standing, ${ }^{123}$ group litigation, ${ }^{124}$ cities, ${ }^{125}$ and state action. ${ }^{126}$ This literature is unusually and in some cases extremely well-informed historically, with rewarding consequences. It is able to show that the forms of representation that we happen to use do not exhaust the stock of forms that have been historically available, but that we have been unable to perceive or make use of other forms because of basic conceptual limitations in modern liberal political thought. It thus expands the range of possible forms of social organization and at the same time explains why the possibilities have gone unrealized. If there is any hope of attaining the vision of the universal for which the denial theorists long, it seems likely to be realized through studies such as these of historically contingent particulars.

121. See, e.g., Barnes, The Comparison of Belief-systems: Anomaly Versus Falsehood, in Modes of Thought 182, 186-88 (R. Horton \& R. Finnegan eds. 1973).

122. Hay, supra note 58.

123. See J. Vining, supra note 66, at 13-33.

124. See Yeazell, From Group Litigation to Class Action, Part II: Interest, Class and Representation, 27 U.C.L.A. L. REv. 1067, $1107-20$ (1980).

125. See Frug, The City as a Legal Concept, 93 Harv. L. Rev. 1057, 1081-82 (1980).

126. See Katz, Studies in Boundary Theory: Three Essays in Adjudication and Politics, 28 Buffalo L. Rev. 383, 386-408 (1979). 
Embrace: Legal Theories of Social and Historical Contingency. After considering denial, moving on to embrace comes as a relief because the scholars who choose this strategy at least recognize the problem of historicity and do not think it can be waved away with assertions that nothing important to legal reasoning ever changes. The basic embrace strategy-some version of adaptation theory-has been a valuable heuristic, because it has directed attention to context and forced legal scholars to elaborate ideas about relationships between texts and their contexts. Anyone could have predicted that at first such ideas would reinforce the usual inclinations of legal scholarship toward conservatism or moderate law reform. The claim would be that if there were differences between ideology and practice (the gap), they could be closed by appropriate equilibrating mechanisms, or that if law had been evolving, its evolution was nearly complete, or proceeding at a very gradual rate, or moving (in the characteristically American conservative teleology) toward the unfolding of a pre-existing ideal.127

What is frustrating and alarming is that the intellectual development of legal scholarship has so often stalled at this initial level of response, and repelled, retarded, or pushed off to the margins most attempts to go beyond it. I do not think it needs much demonstration that legal history and the sociology of law have become marginal subspecialties in American law curricula, though there was a time in the founding years at Harvard when every course was partly a legal history course. Likewise, for a moment in the 1920s, much of the Columbia faculty dreamed that every course might be partly one in sociology. I have tried elsewhere to tell the story of how the law schools ejected legal history when it betrayed them by abandoning evolutionism. ${ }^{128}$ John Schlegel, in a fascinating article, ${ }^{129}$ has been telling a similarly dispiriting story about Yale's experiments with empiricism. One of Schlegel's stories will serve as a parable. It had long been an article of faith among moderate law reformers in the profession and the schools that the people, as Pound put it, were dissatisfied with the administration of justice, ${ }^{180}$ and that the cause must be the delay and expense of court proceedings, which were in turn caused by unreformed law and procedure. At the high point of the rage for em-

127. See S. BERcovitch, supra note 36 (discussing teleology of American mission); $R$. WELTER, supra note 36 (same).

128. Gordon, J. Willard Hurst and the Common Law Tradition in American Legal Historiography, 10 LAW \& SOc'Y REv. 9, 17-19 (1975).

129. Schlegel, American Legal Realism and Empirical Social Science: From the Yale Experience, 28 Bursalo L. Rev. 459 (1979).

130. Pound, The Causes of Popular Dissatisfaction with the Administration of Justice, 29 A.B.A. REP. 395, $416 \cdot 17$ (1906). 
pirical research in the early 1930s, the Wickersham Commission in effect asked Dean Clark of Yale and his research team to verify those propositions. But the Clark team's study of the lower criminal courts found anything but undue delay owing to excessive technicality; the system, they said, "seems almost too efficient; because it presents the spectacle of a long line of orderly offenders, few of whom it is necessary to commit to jail either before or after trial, pleading guilty with systematic regularity . . . raising no technical objections . . . "131 This discovery no longer surprises us, but it did Clark's contemporaries in academic law, who concluded in effect that it must be wrong. Disenchantment with empiricism soon followed; in a few years, it had all but vanished. ${ }^{132}$

Adaptation theory, however, survived. Legal scholars continued to assert that law was an adaptive technology: that legal forms had adapted or could be adapted to serve given social functions, purposes, or interests, and that some forms and institutions were especially adaptive (or "competent") for some functions, and grossly maladaptive (or "incompetent") for others, the most common, but by no means only, assertions being those about what courts were intrinsically good or bad at doing. These arguments-as it is the professional function of one of our best if definitely marginal journals, the Law \& Society Review, periodically to lament ${ }^{133}$-have in general been carried on in a wilderness almost completely devoid of knowledge or apparent interest in knowledge about what, for example, courts and legislatures in this society actually do.

In particular, one might have hoped that by now our legal scholars would have developed adaptation theory from a set of ad hoc insights into a full-scale historical sociology of law, in the tradition

131. Schlegel, supra note 129 , at 504 (quoting Douglas, Arnold, \& Clark, Progress Report on the Study of Business of the Federal Courts 3 (n.d.) (draft) (in Clark Papers, Beinecke Library, Yale University)).

132. Gilmore, And Now for Something Completely Different (Book Review), LAw Alumni J., Summer 1975, at 38, 38 (Univ. of Chicago) (by early 1940s, "entire law faculty" at Yale viewed law as "a sort of mystical absolute"). The substantive unacceptability of the conclusions of historical and sociological scholarship, is, as the Schlegel article makes clear, only one of the reasons for their disappearance from the legal mainstream. Others are their alien methodologies, the lack of interest taken by most mainstream historians and sociologists in legal subjects, and perhaps above all, their tendency to make any problem on which they are brought to bear seem more complex and ambiguous, and its solution more indeterminate, than it was before they were consulted. As Douglas Hay said to me at the symposium, the maturing of history as a discipline in the late nineteenth century made it increasingly unusable for any immediately practical legal purpose: any field that historians had well trampled was a tremendous battleground of specialized professional controversy.

133. See, e.g., Cavanagh \& Sarat, Thinking About Courts: Toward and Beyond a Jurisprudence of Judicial Competence, 14 LAW \& SOC'Y REv. 371 (1980). 
of Weber, that would try to relate in a more or less systematic way changes in legal forms to those in economy and society. ${ }^{134}$ But in fact, outside the books of Willard Hurst and his Wisconsin school, I can think of only a handful of such studies in our scholarship, notably Dawson's on contract law in inflationary economies. ${ }^{135}$ There are signs of a revival: the entrepreneurial histories of Alfred Chandler have inspired a resurgence of interest among legal scholars in the contribution of legal technologies to corporate concentration in the late nineteenth century; ${ }^{138}$ Robert Clark has been developing an unusually detailed neo-Weberian evolutionary model to explain changes in corporate law in a capitalist economy; ${ }^{137}$ in extraordinary comparative work, Mirjan Damaska has explored the connection between rules and processes of criminal procedure, and variations in the structures of political authority; ${ }^{138}$ and Ian Macneil, Oliver Williamson, and Richard Danzig have developed functional theories of the relation of contract law to patterns of economic organization. ${ }^{139}$

Had more of this work been done earlier, and been absorbed into the bloodstream of the discipline, critical response to it, stressing some of the theoretical limitations of adaptationism-the problems of discontinuity between formal expression and applications, of false dualism between "law" and society, of the indeterminate and contradictory character of regimes of legal form, which makes it difficult to show that any particular one is instrumental to any given economic order-might have stimulated other kinds of historically minded scholarship.

One example might be scholarship that set aside entirely the premise that the primary importance of legal texts lies in their functionally

134. For recent work explicitly in this tradition, see R. UNGER, LAW IN MODERN SOCIETY (1976), and Trubek, Toward a Social Theory of Law: An Essay on the Study of Law and Development, 82 YALE L.J. 1, 40.50 (1972).

135. See Dawson, Effects of Inflation on Private Contracts: Germany, 1914-1924, 33 Micr. L. Rev. 171 (1934); Dawson \& Cooper, Effects of Inflation on Private Contracts: United States, $1861-1879$ (pts. 1 \& 2), 33 MICH. L. REv. 706, 852 (1935).

136. See Managerial. Hierarchies (A. Chandler \& H. Daems eds. 1980); Recht und ENTHICKLUNG DER GROSSUNTERNEHMEN IM 19. UND FRÜHEN 20. JAHRHUNDERT (N. Horn \& J. Kocka eds. 1979).

137. See Clark, The Four Stages of Capitalism: Reflections on Investment Management Treatises, 94 HARv. L. REv. 561 (1981); Clark, The Interdisciplinary Study of Legal Evo. lution, 90 YALE L.J. 1238 (1981).

138. See Damaška, Presentation of Evidence and Factfinding Precision, 123 U. PA. L. REv. 1083 (1975); Damažka, Structures of Authority and Comparative Criminal Procedure, 84 YALE L.J. 480 (1975).

139. See I. Macneid, The New Social Contract (1980); Danzig, Hadley v. Baxendale: A Study in the Industrialization of the Law, 4 J. LeGAL STUD. 249 (1975); Williamson, Transaction-Cost Economics: The Governance of Contractual Relations, 22 J.L. \& Econ. 233 (1979). 
serving some set of manifest socia's needs, and took discontinuity as its starting point. This approach could lead to an historical perspective on "legal pluralism," state-promoted norms competing with others or for that matter, cooperating with others in a division of hegemonic labor; alternatively, it could lead to a focus on the "latent" function of even apparently maladaptive law. Douglas Hay's essay on the criminal law ${ }^{140}$ is a stunning example of what can be sai! about the legitimating functions of unenforced rules. Arthur Leff, in a characteristically bravura performance, has sketched a map of a completely new and potentially valuable territory of symbolic meanings of legal texts that legal scholars who are tired of the old responses can explore. ${ }^{141}$

Adaptation theory in all its forms, as I have pointed out, assumes that the social functions to which law is instrumental-interests, purposes, needs-are exogenous to the legal system. That is, states need security against foreign enemies, economies need growth, business people need security of transactions, everyone needs free expression and protection of property, and so forth. This false dualism makes it hard to see how the legal order also helps to construct the social world whose functions it serves: the "persons" and their "interests" and the "harms" to those interests, not to mention "states" and "markets." We are now suddenly getting a flood of articles that address the legal construction of social categories; this includes the literature on the theme of representation ${ }^{142}$ and a novel genre of legal history that treats legal doctrine as ideology, a way of structuring social experience that seems to be a functional response to social needs but is in fact a way of making the existing order seem natural and necessary. ${ }^{143}$

From Cartesianism to Rhetoric. I referred earlier to a quasi-Cartesian mode of response that legal scholars implicitly adopt whenever they say to the historicist critic: "All this social and historical contingency you talk about is no doubt highly interesting, but it is really irrelevant to our task as lawyers, which is to work within a

140. See Hay, supra note 58.

141. See Leff, $L a w$ and, 87 YALE L.J. 989 (1978). Leff has often written in the mode of resignation, but instead of using it as a device for keeping historicism at bay, he has fully incorporated historicist perspectives in his work and helped to advance the dialogue as much as anyone now writing.

142. See p. 1050 supra.

143. See, e.g., M. Tushnet, Considerations of Humanity and Interest: The American LAW of SLAverY, 1810-1860 (forthcoming 1981, Princeton University Press); Kennedy, supra note 67; Klare, Judicial Deradicalization of the Wagner Act and the Origins of Modern Legal Consciousness, 1937-1941, 62 MinN. L. REv. 265 (1978). 


\section{Historicism}

certain well-established framework of normative analysis that takes some basic premises about law-in-society-and-history as stipulated and not open to question." This response is plausible enough, as far as it goes. Many of the criticisms that historians make of lawyers' history are indeed irrelevant to the lawyer's task. At least the immediate interest of historians is always in "historicizing" the past as much as possible, tamping it down firmly into departed times and places. ${ }^{144}$ For lawyers, this method is useful only half the time, when they want to get rid of some practice justified by tradition. At other times they want not to deaden the past but to make new, mythic, traditions out of it to use in current argument. It is pointless to say that such myths are "inaccurate" from the standpoint of conventional historiography, for they are so by definition. But that does not mean that all historicist criticism of legal rhetorics is irrelevant, because the critic could take the rhetorics on their own terms, instead of the conventional historian's terms, and say, "This is bad mythmaking."

What would such criticism look like? It is hard to say, because the dialogue hypothesized has yet to take place. Perhaps it would take the form of objections that the lawyers' mythic uses of the past are flawed because myopic or incomplete, ignoring aspects of legal traditions that are alternative sources of organizing or inspiring myths. From this perspective, for instance, it might be possible to develop the arguments, sometimes hinted at by historicist critics, ${ }^{145}$ that current legal rhetoric, by confining itself to dessicated, liberal individualist or interest-group theories of politics, has cut itself off from the civic humanism of the republican ideology of the founding generation, an ideology that has been periodically resurgent in our politics $^{146}$ and that our scholarship should try to reincorporate into our standard normative reasoning modes.

Envoi. There seems, in view of these suddenly blooming wildflowers, reason to hope that our mainstream legal scholarship may at last have been shaken out of its old habits. Yet one cannot be too confident of this. Its basic paradigms, especially adaptation theories, have proved quite amazingly resilient to shock after shock. Because they assume a benign continuity between law and social change,

144. See M. OAKEshotr, The Activity of being an Historian, in Ratronalism In PoLrTics 137, 164-67 (1962).

145. For versions of such arguments, see Brest, supra note 53, at 1105-09, Frug, supra note 125, at 1087-90, and Michelman, Politics and Values or What's Really Wrong with Ra. tionality Review? 13 Creichton L. Rev. 487, 506-10 (1979).

146. See Ross, The Liberal Tradition Revisited and the Republican Tradition Addressed, in NEw Directions in American Intellectual History 116 (J. Higham \& $P$. 
rather than taking it as problematir. such theories have inhibited the development of richly empirical and historical descriptions of how people in society, lawyers and others, actually experience their legal order. While seeking to make the law more effective in the name of a pragmatic empiricism, these theories have restricted thinking about law to minor changes in its present forms, thereby preventing us both from learning what law as experienced in social life is really like and from imagining that law might be other than the way it is. Adaptation theory has been the most subtly apologetic of the responsive modes, because it views "society" and "history" as a largely determined background of forces that nobody can do much about, but sees "law" as the largely free creation of lawyers and jurists, who can adapt to predetermined social change more or less efficiently, depending on how cleverly they design institutions or doctrines. The theory is thus doubly misleading because it denies our responsibility for the ways in which legal ideas contribute to the constitution and reproduction of the society "out there" and denies the social contingency of our thinking about law, which drastically (and in my view unnecessarily) restricts its range.

There is no use pretending that some extraordinary new revelation is at hand, but the work that I have described (and much other work as well) seems to help point the way out of this curious impasse, to move legal scholarship beyond its long practiced modes of response. Yet virtually all this work, in one way or another, transgresses the principal ambitions of our scholarship: some of it claims that much of current law, instead of making sense, is contradictory and incoherent; some of it that current law in operation is ineffectual or harmful; and from practically none of it could anyone extract an immediately useful policy proposal. For some people, this last fact alone settles the matter: why are we wasting their time? But even they might pause to consider that if work, otherwise interesting, does not generate what the paradigm considers acceptable conclusions, perhaps the fault lies with the paradigm. What is being proposed here, and in the work $I$ have described, is a kind of reverse Faustian bargain: our sacrifice of immediate influence in the councils of the great for a potentially enormous increase in understanding of our condition. 